\title{
Diversity, density and distribution of termites in housing complexes in Purwokerto, Central Java, Indonesia
}

\author{
HERY PRATIKNYO", TRISNO HARYANTO, DWI NURCAHYO APRIYANTO \\ Faculty of Biology, Universitas Jenderal Soedirman. Jl. Dr. Suparno No. 63, Purwokerto Utara, Banyumas 53122, Central Java, Indonesia. \\ Tel./fax.: +62-281-625865, `email: hery.pratiknyo17@gmail.com
}

Manuscript received: 27 October 2020. Revision accepted: 24 November 2020.

\begin{abstract}
Pratikno H, Haryanto T, Apriyanto DN. 2020. Diversity, density, and distribution of termites in housing complexes in Purwokerto City, Central Java Indonesia. Biodiversitas 21: 5729-5735. Termite attacks have detrimental effects on buildings and incur considerable costs. The rapid development of housing complex in Purwokerto City, Central Java Province, Indonesia urges an investigation on the occurrence of termite attacks. This research aimed to identify the diversity of termite species, its spatial distribution and its density on a variety of wood on housing complexes in Purwokerto City and the surrounding areas. The context of this study focused on wood species commonly used by the developers, namely albasia (Paraserianthes falcataria), which is commonly used for the upper ceiling, bangkirai (Shorea laevifolia) for poles and door/window frames, and teak (Tectona grandis) which is often used for door and window boards. We used bait techniques with the rationale that it is cheap and environmentally friendly as well as accurate. Four housing complexes in four subdistricts were randomly selected stratified based on four altitude ranges ( $<100 \mathrm{~m}, 100 \mathrm{~m}, 200 \mathrm{~m}$, and $300 \mathrm{~m})$. In each selected housing complex wood baits of three durability types (i.e. albasia, bangkirai and teak) were installed, each measuring $30 \mathrm{~cm} \times 2 \mathrm{~cm} \times 2 \mathrm{~cm}$ with five replications. Data of termite species, spatial distribution of termite species, and individual density in each housing complex were recorded after three months since the wood baits were stockpiled. Microclimate variables during the study were also recorded. The differences in density across housing complexes and the three types of wood were tested using ANOVA and continued with Duncan's test. The results showed three species of termites attacked wood baits, namely Microtermes insperatus, Macrotermes gilvus, and Odontotermes javanicus, all belong subterranean termite group. $M$. insperatus and $O$. javanicus had specific spatial distribution without overlapping zone among the two, while $M$. gilvus was the most adaptable and widely distributed in all housing complexes $(<100-300 \mathrm{~m}$ asl.) regardless of the durable quality of the wood. There was significant difference in termite attacks across housing complexes with Ketapang housing complex in Sokaraja Subdistrict $(<100 \mathrm{~m}$ asl.) was most frequently attacked. Conversely, there were no significant differences in termite attacks across the three types of wood (i.e. albasia, bangkirai, and teak).
\end{abstract}

Keywords: Altitude, settlement, termites, wood durable quality

\section{INTRODUCTION}

Termites are a group of insects that cause significant harm by destroying buildings. Drywood and subterranean termites are the most destructive insect pests of wood causing more than US\$ 1.7 million damage each year in the United States (Aludairo et al. 2016) and Japan are around 800 million US\$ a year, respectively (Verma et al. 2009). In Europe, the losses caused by termites are estimated at 313 million US\$ per year (Eggleton 2000). Economic losses due to termite in India have been estimated at around 35.12 million US\$ (Joshi et al. 2005). The global economic impact of termite pests is estimated to be at least US $\$ 40$ billion (Rust and Su 2012). In Southeast Asia region, the damages caused by termite attacks on various facilities reach US\$ 10 million per year. Such as in Malaysia 8 million US\$ is spent toward termite treatment every year (Lee 2002). In Indonesia itself, the damage to buildings caused by termite attacks in year 2000 was up to US\$2.67 million. Particularly in housing development sector in Indonesia, losses due to termite infestation contribute to $12.5 \%$ of the total housing development costs each year (Rachmawati, 2016). For example, in Banyumas District, Central Java Province, the number of public housing in rural areas suffering damage from termite attacks reached $86.25 \%$ (Wahyuni et al. 2000). Such problem causes a heavy burden for the rural communities, most of whom still use wooden houses and semi-permanent houses with the primary construction material dominated by wood.

As social insects, termites have a division of caste and work. The castes work together to accomplish specific and complementary tasks within a colony. Division of labor among castes is the key to efficient colony development, survival, and reproduction (Haifig et al. 2016). The higher the number of worker castes that attack a location, the greater the size of the termite colony of that species. Instinctively, each termite colony is bound and held together by a social pheromone produced by the termite queen and propagated by and to members of the working caste through the behavior of feeding each other (trophallaxis) (Nandika et al. 2003). Based on this social pheromone odor, a colony of termites within one species recognizes each other and physically develops a separate colony from other territories of different species. Then separately, termite communities from various species attack wood material to obtain cellulose and obtain the right conditions to grow the termitomycetes group of fungi as a protein source. 
Purwokerto City, as the center of government for Banyumas District, Central Java Province, Indonesia and the surrounding areas have very rapid development of residential housing complexes. Such complexes have mostly developed on previously irrigated rice fields that were converted into human settlements, expanding from Baturaden Subdistrict on the southern slope of Mount Slamet (300 m asl.) to Banyumas old town area $(<100 \mathrm{~m}$ asl.). Various models and sizes of housing complex have been developed, from cluster model consisting of only a few housing units to a large housing complex such as Perumnas (a project run by government). In general, the building construction utilizes a mixture of low, medium, and high quality wood, including albasia (Paraserianthes falcataria syn. Albizia falcataria), bangkirai (Shorea laevifolia), and teak (Tectona grandis). Despite the rapid development of human settlements in Purwokerto City and Banyumas District, a study suggested that $20 \%$ of such housing development were attacked by termite's infestations (Wahyuni et al. 2000).

The high level of termite infestation in Purwokerto City and the surroundings is likely caused by several factors, including climate, wood quality and environmental sanitation. The climate of Purwokerto City and the surroundings is classified as B2-C2, which is characterized by very high rainfall (2456-3895 $\mathrm{mm}$ per year), and average daily temperature of $25.4^{\circ} \mathrm{C}$, and average relative humidity of $75 \%$ (Oldeman 1978). These climate conditions are very suitable to support termite life. Cao and $\mathrm{Su}$ (2015) stated that temperatures of $20-34^{\circ} \mathrm{C}$ and air humidity of $80-95 \%$ are the optimal climates for the development of termites colony. Rao et al. (2012) found significant correlation between air temperature and the occurrence of two genera from Termitinae sub-family, one of them is the genus of Macrotermes that relatively more dominant at higher temperature. This fact indicates that stable air temperature and humidity on certain range is potentials to support Macrotermitinae subfamily of Termitidae Family (Grieco et al. 2009).

The quality of wood used in the construction of housing complexes also plays an essential role in the emergence of termite attack. There are three grades of wood durability against termite attack: i.e. low, medium, and high. Group of wood with high cellulose content and low lignin extractive substances, such as $P$. falcataria is more preferable for termite attacks. On the other hand, group of wood with a balanced content of cellulose and lignin, such as $S$. laevifolia has moderate durability, while high durable wood is characterized by low cellulose content but very high lignin, such as T. grandis. Albasia wood is classified as low durable grade (class 5) with a specific gravity of 0.33 . Its wood is easily weathered, so termites and fungi quickly attack it due to high content of cellulose with very low lignin and pentosan content. The preference for greater cellulose concentrations could be adaptive for termites and their symbionts. Food with higher concentrations of cellulose is probably more digestible for termites (Judd and Corbin, 2009). This type of wood is classified as sapwood and it has lower durability than terrace wood (Tobing, 1977). S. laevifolia wood is medium durable grade with a specific gravity of 0.91 with high content of lignin compounds. Its terrace wood is darker due to its high extractive lignin concentration and is more resistant to termite attack (Haygreen and Bowyer 1996). Conversely, wood with higher concentration of lignin is not easily digested by termites (Waller and La Fage 1990). The high durable grade wood, such as $T$. grandis, has high strength since it is composed of $47.5 \%$ cellulose, $30 \%$ lignin, $14.5 \%$ pentosan, and tectoquinone (2-methyl anthraquinone) and terpenes (Fengel and Wegener 1984).

Environmental sanitation factors when developing housing complexes are also crucial in influencing termites occurrence. The application of termiticide treatment on the soil during the pre-construction period can reduce the risk of termites infestation (Nandika et al. (2003). In addition, wood wastes piled around the building can invite termites, suggesting that proper management of wood materials and wastes is important to avoid termites' emergence.

So far, research on the damages caused by termite attacks, specifically in the housing sector built by developers in Purwokerto and Banyumas region, has never been carried out. This research aimed to identify the species of termite, its spatial distribution, and its density on a variety of wood on housing complexes in Purwokerto City and the surroundings.

The context of this study focused on wood species commonly used by the developers, namely $P$. falcataria (albisia), which is commonly used for the upper ceiling, $S$. laevifolia (bangkirai) for poles and door/window frames, and $T$. grandis (teak) which is often used for door and window boards.

\section{MATERIALS AND METHODS}

\section{Study period and area}

The research was conducted from February 2020 to May 2020, in Purwokerto City and the surrounding areas of Banyumas District, Central Java Province, Indonesia (Figure 1). It is located at E $90^{\circ} 17^{\prime} 20^{\prime \prime}-90^{\circ} 18^{\prime} 40^{\prime \prime}$ and S $7^{\circ} 10^{\prime}$ and $7^{\circ} 30^{\prime}$ and altitude between $<100 \mathrm{~m}-300 \mathrm{~m}$ asl. The air temperature is $24.4-32.9^{\circ} \mathrm{C}$ with relative humidity of 60 $85 \%$, annual rainfall of $2000-4000 \mathrm{~mm}$ per year. The soil type is gray alluvial with brown latosol-regosol association.

\section{Data collection}

The research used a survey method with stratified random sampling technique. The study areas (Purwokerto City and surroundings) were stratified into four subdistricts based on altitude (<100 m, $100 \mathrm{~m}, 200 \mathrm{~m}$, and $300 \mathrm{~m})$. In each subdistrict, one housing complex was selected randomly. Each selected housing complex, was randomized five locations were then selected as replications. Sampling area is shown in Table 1.

\section{Data analysis}

The differences in termite density attacked the logs and housing complexes were analyzed using ANOVA model II at confidence level of $95 \%$ and $99 \%$. If there was significant or very significant difference, the Duncan test was then conducted to determine where the difference. SPSS program was used for the statistical tests. 


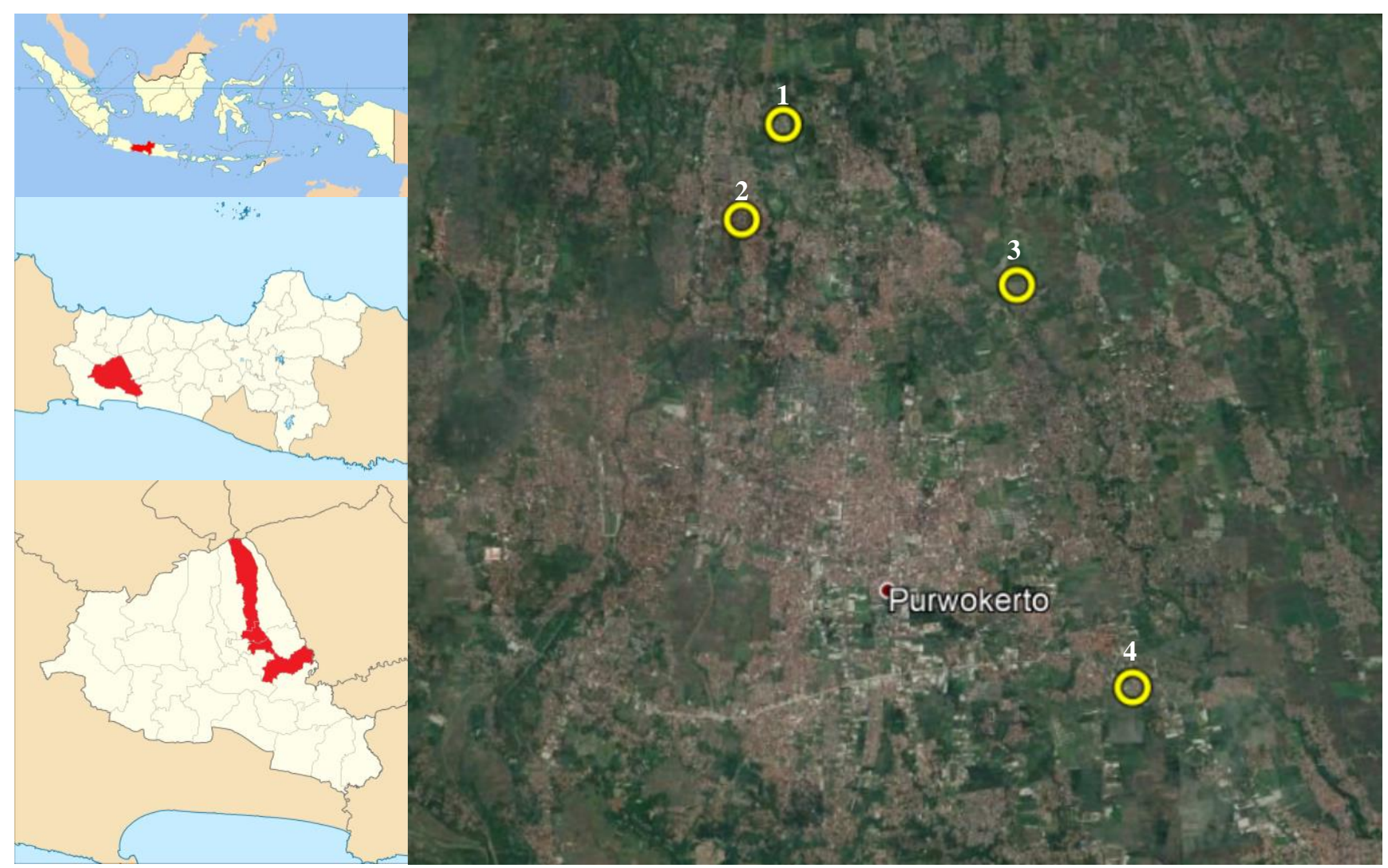

Figure 1. Area sampling of termites in Purwokerto City and surrounding areas, Central Java, Indonesia. No. of location refer to Table 1.

Table 1. Area sampling of housing complexes and the characteristic

\begin{tabular}{|c|c|c|c|c|c|c|c|}
\hline No. & $\begin{array}{c}\text { Name of housing } \\
\text { complex }\end{array}$ & $\begin{array}{c}\text { Subdistrict-distance from } \\
\text { Mount Slamet crater }\end{array}$ & $\begin{array}{l}\text { Area } \\
\text { Size }\end{array}$ & Altitudes & $\begin{array}{c}\text { Year } \\
\text { of built }\end{array}$ & $\begin{array}{c}\text { Typical size of } \\
\text { house }\left(\mathbf{m}^{2}\right)\end{array}$ & $\begin{array}{c}\text { Daily average of } \\
\text { abiotic variable }\end{array}$ \\
\hline 1 & Langen Estate & Baturaden; $3 \mathrm{~km}$ & 20 ha & $300 \mathrm{~m}$ asl. & 2005 & $36 ; 45,54$ and 70 & $30^{\circ} \mathrm{C} ; 80 \% ; 13 \operatorname{lux}$ \\
\hline 2 & Sumampir Indah & North Purwokerto; $5 \mathrm{~km}$ & 25 ha & $200 \mathrm{~m}$ asl. & 2000 & $36 ; 45,54$ and 70 & $31^{\circ} \mathrm{C} ; 75 \% ; 14 \operatorname{lux}$ \\
\hline 3 & Shapphire Estate & East Purwokerto; 6 km & 30 ha & $100 \mathrm{~m}$ asl. & 2003 & $36 ; 45,54$ and 70 & $32^{\circ} \mathrm{C} ; 70 \% ; 15 \operatorname{lux}$ \\
\hline 4 & Ketapang Indah & Sokaraja; $20 \mathrm{~km}$ & 25 ha & $75 \mathrm{~m}$ asl. & 1999 & $36 ; 45,54$ and 70 & $33^{\circ} \mathrm{C} ; 65 \% ; 16 \operatorname{lux}$ \\
\hline
\end{tabular}

\section{RESULTS AND DISCUSSION}

This study found three subterranean termites in the studied area, namely Odontotermes javanicus, Microtermes insperatus, and Macrotermes gilvus (Figure 2). These three species belong to the subfamily Macrotermitinae of the Termitidae family. Species $M$. gilvus and $O$. javanicus were found et all (four) housing complexes, while $M$. insperatus was found in two housing complexes. The main characteristic of these three species is that they build a wandering canal that connects the nest location with the attacked site. The wandering canal is made with the substrate around the attacked site. In soil habitats, the protective walls of the wandering canal are made of soil, but in the karst habitats, the protective walls are built from karst material (Pratiknyo and Setyowati 2020). Nandika et al. (2003) stated that living subterranean termites are always in contact with the soil, although their attacked site is above the ground (arboreal).

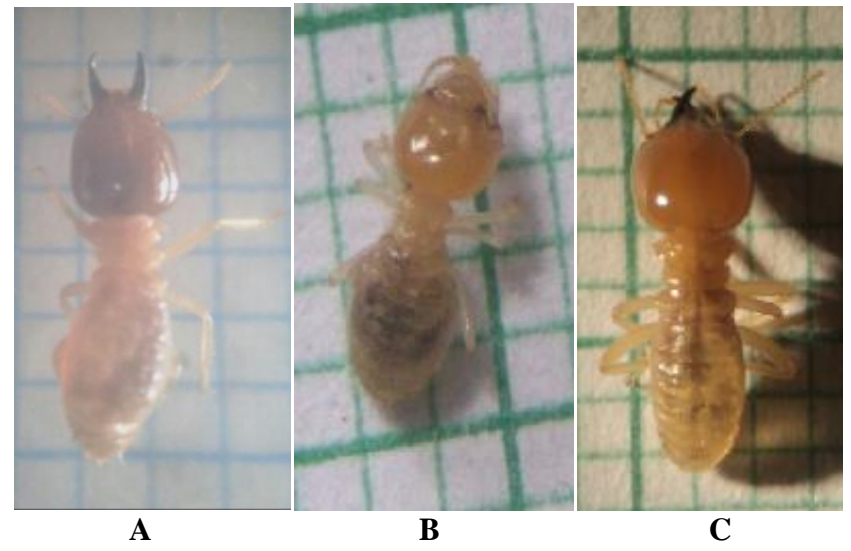

Figure 2. A. Odontotermes javanicus, B. Microtermes insperatus, C. Macrotermes gilvus 
The presence of termites from the Termitidae family is not surprising because the Termitidae family has an extensive distribution, even reaching an altitude of $3000 \mathrm{~m}$. According to Nandika et al. (2003), the Termitidae is family with the highest number of members, and about $85 \%$ of the termite species identified belongs to the Termitidae family. In the tropics, termites are found from the coast to an altitude of $3000 \mathrm{~m}$ asl. with a narrow spatial distribution between latitudinal $5^{0} \mathrm{~N}$ and $5^{0} \mathrm{~S}$. These three species of subterranean termites are high-level groups. Apart from consuming wood, they also consume Termitomycetes fungi as a source of protein. Bignel and Eggleton (2011) state that there are four categories of termites, namely wood-eating or low-level, fungi-eating or high levels, eating rotten organic substances, and eating pure soil.

The abundance of M. gilvus was the highest with 1100 individuals followed by $O$. javanicus with 234 individuals and $M$. insperatus with 174 individuals (Table 2). The exciting thing about this finding was the individual abundance of $M$. gilvus was inversely proportional to the increase in the housing complex's altitudes, where the abundance of $M$. gilvus getting lower with the increasing altitude. This is in line with Inoue et al. (2006) that stated the Macrotermitinae sub-family decreases in abundance with the increasing altitudinal elevation. In this case, Gathorny-Hardy et al. (2001) explained that every $100 \mathrm{~m}$ increase, air temperature will reduce about $1^{\circ} \mathrm{C}$, thus affecting the metabolic activity of termites as poikilothermic fauna. This fact suggests that $M$. gilvus species is not adaptive to air temperature changes, humidity, and light intensity due to altitude elevation.

Our study found that termites' attacks varied across housing complexes, positions and types of logs (Table 3 ). In addition, the spatial distribution of termite attacks in each log showed no overlapping distribution, suggesting that each log was attacked by one termite species (Table 4).
The spatial distribution of $M$. insperatus was broader, which were found in two housing complexes, while $O$. javanicus was only found in one housing complex.

The species $O$. javanicus only attacked in Ketapang-4 in subdistrict Sokaraja, which geographically is the lowest elevation $(<100 \mathrm{~m}$ asl.), and attacked all three wood species. It was supposed that $O$. javanicus developed well in Ketapang-4 because the temperature of $33^{\circ} \mathrm{C}$ was ideal for the development of their colony. This activity suggests that $O$. javanicus is an opportunistic social insect. The colony did not distinguish the wood grade, either the low grade $(P$. falcataria) and the high grade $(T$. grandis). This ability is supported by the strong-giant mandible and big size of the body they have. On the other hand, $M$. insperatus attacks were found in Langen housing complex 1 (Langen 1) and Sumampir housing complex 2 (Sumampir-2) with the higher altitude (200 and $300 \mathrm{~m}$ asl.), and only attacked the low and medium qualities wood. The small body size supports the habits of consuming low and medium durable quality wood. Taxonomically, these three species belong to the Subfamily Termitinae but they have different optimal temperatures and humidity according to their metabolic needs.

The local microclimate (air temperature, relative humidity and sunlight intensity) in Ketapang housing complex 4 (Ketapang-4) $\left(33^{\circ} \mathrm{C} / 65 \% / 16\right.$ lux, alt $\left.<100 \mathrm{~m}\right)$ was different to Langen- $1\left(30^{\circ} \mathrm{C} / 80 \% / 13\right.$ lux, alt $=300 \mathrm{~m}$ asl.), Sumampir-2 $\left(31^{\circ} \mathrm{C} / 75 \% / 14 \mathrm{lux}\right.$, alt $=200 \mathrm{~m}$ asl. $)$ and Shapphire housing complex 3 (Shapphire-3) $\left(32^{\circ} \mathrm{C} / 70 \% / 15\right.$ lux alt $=100 \mathrm{~m}$ asl.). This means that $O$. javanicus prefers local microclimate with higher temperature, lower humidity, and brighter sunlight. Likely $M$. gilvus is the most adaptable on various conditions, their colony developed better at higher temperature and lower relative humidity, similar to O. javanicus. But, the colony of $M$. gilvus also developed well in lower temperature and higher humidity and less sunlight of Ketapang-4.

Table 2. The individual abundance of species across housing complexes

\begin{tabular}{lccccc}
\hline Species & Langen-1 & Sumampir-2 & Shapphire-3 & Ketapang-4 & $\begin{array}{c}\text { Total } \\
\text { abundance }\end{array}$ \\
\hline M. gilvus & 167 & 242 & 264 & 427 & 1100 \\
M. insperatus & 86 & 88 & 0 & 0 & 174 \\
O. javanicus & 0 & 0 & 0 & 234 & 234 \\
\hline
\end{tabular}

Table 3. The density of termites across housing complexes, positions and type of log

\begin{tabular}{|c|c|c|c|c|c|c|c|c|c|c|c|c|}
\hline \multirow{2}{*}{ Site } & \multicolumn{3}{|c|}{ Langen-1 } & \multicolumn{3}{|c|}{ Sumampir-2 } & \multicolumn{3}{|c|}{ Shapphire-3 } & \multicolumn{3}{|c|}{ Ketapang-4 } \\
\hline & $\mathbf{A}$ & B & $\mathbf{C}$ & $\mathbf{A}$ & B & $\mathbf{C}$ & $\mathbf{A}$ & B & C & $\mathbf{A}$ & B & $\mathbf{C}$ \\
\hline Location 1 & 0 & 0 & 0 & 65 & 0 & 0 & 0 & 0 & 0 & 130 & 0 & 60 \\
\hline Location 2 & 0 & 0 & 0 & 72 & 0 & 0 & 126 & 15 & 27 & 97 & 15 & 34 \\
\hline Location 3 & 97 & 0 & 0 & 0 & 16 & 0 & 96 & 0 & 0 & 115 & 10 & 40 \\
\hline Location 4 & 0 & 25 & 0 & 0 & 31 & 26 & 0 & 0 & 0 & 139 & 21 & 0 \\
\hline Location 5 & 86 & 0 & 45 & 81 & 0 & 39 & 0 & 0 & 0 & 0 & 0 & 0 \\
\hline Density per logs (individu) & 183 & 25 & 45 & 218 & 47 & 65 & 222 & 15 & 27 & 481 & 46 & 134 \\
\hline Density (individu) & & 253 & & & 330 & & & 264 & & & 661 & \\
\hline
\end{tabular}

Note: A: P. falcataria, B: S. laevifolia, C: T. grandis 
Table 4. Spatial distribution of termite attacks across species, types of log, and housing complexes

\begin{tabular}{lcccccccccccc}
\hline Site & \multicolumn{3}{c}{ Langen-1 } & \multicolumn{3}{c}{ Sumampir-2 } & \multicolumn{3}{c}{ Shapphire-3 } & \multicolumn{2}{c}{ Ketapang-4 } \\
& $\mathbf{A}$ & $\mathbf{B}$ & $\mathbf{C}$ & $\mathbf{A}$ & $\mathbf{B}$ & $\mathbf{C}$ & $\mathbf{A}$ & $\mathbf{B}$ & $\mathbf{C}$ & $\mathbf{A}$ & $\mathbf{B}$ & $\mathbf{C}$ \\
\hline Location 1 & 0 & 0 & 0 & $\mathrm{Mg}$ & 0 & 0 & 0 & 0 & 0 & $\mathrm{Mg}$ & 0 & $\mathrm{Mg}$ \\
Location 2 & 0 & 0 & 0 & $\mathrm{Mg}$ & 0 & 0 & $\mathrm{Mg}$ & $\mathrm{Mg}$ & $\mathrm{Mg}$ & $\mathrm{Mg}$ & $\mathrm{Mg}$ & $\mathrm{Oj}$ \\
Location 3 & $\mathrm{Mg}$ & 0 & 0 & 0 & $\mathrm{Mi}$ & 0 & $\mathrm{Mg}$ & 0 & 0 & $\mathrm{Mg}$ & $\mathrm{Mg}$ & $\mathrm{Oj}$ \\
Location 4 & 0 & $\mathrm{Mg}$ & 0 & 0 & $\mathrm{Mg}$ & 0 & 0 & 0 & 0 & $\mathrm{Oj}$ & $\mathrm{Oj}$ & 0 \\
Location 5 & $\mathrm{Mi}$ & 0 & $\mathrm{Mg}$ & 0 & $\mathrm{Mg}$ & 0 & 0 & 0 & 0 & 0 & 0 & 0 \\
\hline
\end{tabular}

Note: A: P. falcataria, B: S. laevifolia, C: T. grandis; Mg: M. gilvus, Mi: M. insperatus, Oj: O. javanicus, 0: no termites found

These results are in line with statement of GathornyHardi et al. (2001) that stated the Macrothermitinae subfamily prefers to hotter air temperatures, and the abundance decreases with the increasing altitude. Another assumption that $M$. gilvus and $O$. javanicus prefer high air temperature with low humidity is these factors can support the growth of Termitomycetes fungi group. According to Korb and Linsmeier et al. (1978), Termitomycetes group grows well at high temperatures and low humidity. On the other hand, $M$. insperatus prefers microclimate with lower air temperature and higher relative humidity.

Another exciting thing was no low-level wood termites, Schedorhinotermes javanicus, found in the studied area. Pratiknyo et al. (2018) found S. javanicus as the dominant species on the south slope of production forest area of Mount Slamet, which is only $5 \mathrm{~km}$ from the location of Langen-1. It supposed, the differences in altitude (700 m$1300 \mathrm{~m})$ with air temperature $\left(18^{\circ} \mathrm{C}\right)$ and relative humidity $(90 \%)$ is an ideal place for S. javanicus species, which were not found in housing complex conditions. Bignel and Eggleton (2011) stated that air temperature and humidity are the main limiting factors for termite life in tropical soil. These findings suggest that the termites attacked the housing complexes in Purwokerto City and the surroundings belong to the group of high-level subterranean termites.

In terms of spatial distribution, there was specificity in termite community where $M$. insperatus was distributed in two housing complexes in Baturaden and North Purwokerto Subdistrict with upper altitude (200 and $300 \mathrm{~m}$ asl.) or closer $(5 \mathrm{~km})$ to Mount Slamet. On the other hand, O. javanicus dominated Ketapang-4 in Sokaraja Subdistrict which has the lowest-altitude $(<100 \mathrm{~m})$ or away $(20 \mathrm{~km})$ from Mount Slamet. Between $M$. insperatus and $O$. javanicus, there was no spatial distribution similarity (housing complex) and never overlap in the single housing complex. It was suspected that the difference in spatial distribution was caused by the presence of social pheromones that bind worker caste termites in one colony. The social pheromones in termites have function to unite the worker caste into one colony (Borror et al. 2016). It was also stated by Nandika et al. (2003) that the behavior of feeding each other (trophallaxis) in the working caste is a social pheromone transfer medium aimed to unify the colony and renew the digestive bacteria that produce cellulase enzymes. The second cause is there were different microclimate requirements for developing colonies. This was in line with Palin et al. (2017) statement that in the tropic, the adaptation ability of several termite species to microclimate factors, especially altitude, is very narrow. In contrast, M. gilvus had the broadest spatial distribution, occurring in all housing complexes studied in four subdistricts (Sokaraja, East Purwokerto, North Purwokerto, and Baturaden) with altitude from $<100 \mathrm{~m}$ asl. to $300 \mathrm{~m}$ asl. This indicates that $M$. gilvus has a relatively wider microclimate range requirement than the other two species.

The results of spatial distribution of termites in this study are in line with several previous studies. According to Tarumengkeng et al. (1971), termites from the genera of Macrotermes and Microtermes are often found simultaneously in one attacked site. This is because the two genera share similar characteristics, often associated with growing fungi and attacking habits. Macrotermes eat fungi at the base, whereas Microtermes eat fungi on top (Krishna and Weesner et al. 1970). In terms of attacks on wooden objects, Microtermes act as pioneers by opening wandering tunnels, only then followed by Macrotermes (Inoue et al. 1998).

In terms of termite attacks on three types of wood, the individual density of termites was statistically not significant ( $F$ tab> 0.05) (Table 5). This means that the termites are opportunistic, meaning that they did not see the quality of the wood grade, and all of the three woods were attacked. This finding is different from Martawijaya et al. (1979) which stated that S. laevifolia wood has a durable quality up to 5 years (grade 2) and is not attacked by termites. Fengel and Wagener (1984) also said that grade 12 wood has high extractive substances, namely agrolesin and pterocarpin. It also contains eusiderin, catechin, and $\beta$ sitosterol (Syafii et al. 1985). On the other hand, $P$. falcataria is classified as grade 5, which is susceptible to termites. However, since the individual density termites attacked the wood did not differ significantly, it indicates that such termites did not prefer certain wood.

The rationales on the indifference in individual density of termites across the qualities of wood include: first, the extractive substance provided by the wood bait was relatively low and mostly water-soluble. Hoarding wood in the ground for one month allowed water to seep into the wood, making the extractive substance drop, consequently, termites' smell detection organ did not work well. Febriansyah et al. (2019) stated that the extractive substance of wood is one factor of repellent for attacking termites. Second, there are opportunistic habits of all termite colonies to utilize the limited cellulose immediately. Worker termites in a colony worked hard in finding cellulose sources and didn't care the distance of 1 $\mathrm{m}$ for the possibility of finding lower quality wood grade. As the main target for termite feed, cellulose will soon be isolated by the colony and immediately explore to benefit colony development. 
Table 5. The Anova results on the individual density of termites across housing complexes and types of wood

\begin{tabular}{llllll}
\hline Source of variance & Sum of square & df & Middle of square & Fcal & Signification \\
\hline Housings & 5.908 & 3 & 1.969 & 4.488 & $0.007^{* *}$ \\
Type of woods & 0.703 & 2 & 0.351 & 0.801 & $0.455^{\mathrm{ns}}$ \\
Replication & 5.135 & 4 & 1.284 & - & - \\
Error & 21.904 & 50 & 0.439 & - & - \\
Total & 48.212 & 59 & - & - & - \\
\hline
\end{tabular}

The significant difference in individual density of termite attacks across housing complexes (Ftab $\leq 0.05$ ) (Table 5) could be explained that there was a clear spatial distribution between the species. For example, $M$. insperatus prefers higher altitude, with lower temperature and higher humidity), while $O$. javanicus prefers lower altitude, with higher temperature and lower humidity. On the other hand, M. gilvus was very adaptive across varying altitudes, ranging from $<100 \mathrm{~m}$ asl. until $300 \mathrm{~m}$ asl. The accumulation of species density of $M$. gilvus and $O$. javanicus in Ketapang-4 makes the total density of the attacking termites was greater than both the accumulation between species density of $M$. gilvus and M. insperatus in Langen housing complexes 1 and Sumampir-2, or single species density of M. gilvus in Shapphire-3.

Duncan's continued test (Table 6) shows that Ketapang4 in Sokaraja Subdistrict is the only housing denser of termites individual than the three others (Langen-1 in Baturaden Subdistrict, Sumampir-2 subdistrict of North Purwokerto and Shapphire-3) subdistrict of East Purwokerto. It is assumed that Ketapang-4 has more suitable microclimate factors for the needs of termites. Ketapang-4 has the longest distance $(20 \mathrm{~km})$ from the forest in Mount Slamet, which was blocked by the city of Purwokerto. The effect of Mount Slamet on the number of rainy days per month in the Banyumas Regency is very different. Areas at the foot of the mountain, such as Baturaden, North Purwokerto, and East Purwokerto Subdistricts, have 25-30 rainy days per month in the rainy season, which was higher than the areas in the lower altitude, such as South Purwokerto, West Purwokerto, and Sokaraja Subdistricts with 20-25 rainy days per month. As a result, the air temperature can reach $>33^{\circ} \mathrm{C}$ with the lowest relative humidity, about $65 \%$, and the sunlight intensity of 16 lux. This condition is constant throughout the year, so it is very suitable for the Termitomycetes fungus to grow. Ketapang-4 is drier and hotter which is ideal for the $O$. javanicus. Even, this species filled out four parts of 15 locations of the three durable wood quality grades, two of which were of high-quality durable grades, implying that Ketapang-4 conditions were very suitable for $O$. javanicus. Sumarni and Ismanto (1988) stated that $O$. javanicus is able to adapt to dry soil by wandering over the surface of the soil looking for sources of cellulose. $O$. javanicus was known as a termite that eats wood, bark and dead trees. In Ketapang-4, with relatively dry soil conditions (soil moisture $51.37 \%$ ), termites were found around the bait wood at a depth of $20 \mathrm{~cm}$.
Shapphire- 3 is located in the eastern of Purwokerto City and was bordered by rice fields. There is a large river (Pelus river) in the western and located on the town's outskirts. It was geographically close $(6 \mathrm{~km})$ to Mount Slamet forest so that the air humidity was higher $(70 \%)$ with air temperature of $32{ }^{\circ} \mathrm{C}$ and the sunlight intensity of 15 lux. In this microclimate, there were no O. javanicus or $M$. insperatus occurred, but M. gilvus showed a relatively high abundance, it could even occupy four parts of 15 positions without distinguishing the durable quality wood grade.

The phenomenon of the absence of $O$. javanicus and $M$. insperatus showed that the microclimate in the- 3 was the limiting factor for these two species. Moist soil factor (soil moisture reaches 63\%) and the absence of trees planted in Shapphire-3 were likely related to the absence of $O$. javanicus. However, further research is needed to prove it.

Sumampir-2 is located in the North Purwokerto Subdistrict (200 $\mathrm{m}$ asl.) with distance of $5 \mathrm{~km}$ from the forest of Mount Slamet and had a dense housing complex adjacent to other complexes. The number of rainy days reached 25-30 days per month in the rainy season, higher than that in Ketapang-4 in Sokaraja Subdistrict. It is located at an altitude of $200 \mathrm{~m}$ asl. and had an average daily temperature $\left(30^{\circ} \mathrm{C}\right)$ and sunlight intensity (14 lux) lower than Ketapang-4. These microclimate conditions were favorable for $M$. insperatus. This species has wide distribution and is often found to attack wood together with M. gilvus. This species occupied one part of 15 positions. They selected only medium-durable wood grade, while $M$. gilvus still dominated, attacked 4 part of 15 positions of two durable quality wood grade although it decreased in abundance compared to housing complexes 3 and 4. As old housing complex (built in 2000), this complex had many trees with old age. Despite the potential to carry out joint attacks with $M$. gilvus, housing 2 did not find such an attack model, suggesting that there is no evidence of any association between termite species (interspecific competition).

Table 6. Duncan test of differences between housing complexes.

\begin{tabular}{lccc}
\hline \multirow{2}{*}{ Housing complex } & Number of & \multicolumn{2}{c}{ Subset } \\
\cline { 3 - 4 } & samples & \multicolumn{1}{c}{$\mathbf{1}$} & $\mathbf{2}$ \\
\hline Ketapang-4 & 15 & -0.0343 \\
Sumampir-2 & 15 & & 0.542 \\
Shapphire-3 & 15 & & 0.7141 \\
Langen-1 & 15 & & 0.7472 \\
\hline
\end{tabular}


Langen-1 was a housing complex located at the highest altitude (300 $\mathrm{m}$ asl.), relatively young (built in 2013), surrounded by irrigated rice fields and not many large trees planted. Langen-1 is located on the northern edge of Purwokerto City, $5 \mathrm{~km}$ from the Mount Slamet Forest. The number of rainy days 25-30 days per month in the rainy season. In wet environment, the air relative humidity was $80 \%$, and average daily temperature of $30^{\circ} \mathrm{C}$, and a sunlight intensity of 13 lux. This microclimatic condition was a preference for $M$. insperatus.

Based on the spatial distribution and individual density, it can be stated that the most adaptive and highest species density of termites in housing complex in Purwokerto City and the surroundings was $M$. gilvus. Species $M$. insperatus had a lower individual density, but it was distributed wider than $O$. javanicus. Among the four housing complexes studied here, there was a significant difference in the individual density of termites attacks with the highest was occurred in Ketapang-4, in altitude $<100 \mathrm{~m}$ asl.

This research concludes that termite species that attacked housing complexes in the studied area belong to the group of subterranean termites. $M$. insperatus and $O$. javanicus have specific spatial distribution without overlapping zone among the two, while $M$. gilvus was the most adaptable and widely distributed in all housing complexes (<100-300 $\mathrm{m}$ asl.) without distinguishing the durable quality of the wood.

\section{REFERENCES}

Ahmad M. 1959. Key to the Indomalayan Termites. Department of Zoology University of Punjabi, Lahore.

Bignel DE and Eggleton P. 2000. Termites in Ecosystems. Kluwer Academic, Dordecht.

Borror DJ, Triplehorn CA, Johnson NF. 2016. Introduction of Insect. McMilan Press, London.

Cao R, Su NY. 2015. Temperature preference of four subterranean termite species (Isoptera: Rhinotermitidae) and temperature-dependent survivorship and wood consumption rate. Ann Entomol Soc Am 109 (1): 64-67.

Davies RG. Hernandes LM, Eggleton P, Didham RK, Fagn LL, Winchester NN. 2003. Environmental and spatial influence upon species composition of a termites assemblage across neotropical forest islands. J Trop Ecol 19: 509-524.

Eggleton P.2000. Global patterns of termite diversity. In Abe T, Bignel DE, Higashi M (eds.). Termites: Evolution, Sociality, Symbiosis, Ecology. Kluwer Academic Publisher, Dordrecht.

FAO 2000. Termite Biology and Management Workshop. Food and Agriculture Organization, Geneva.

Faszly R, Idris AB, Sajap AS. 2005. Termites (Insecta: Isoptera) Assemblages from Sungai Bebar Peat Swamp Forest, Pahang. Biodiversity Expedition Sungai Bebar, Pekan, Pahang.

Fengel D, Wegener G. 1984. Wood: Chemistry, Ultrastructure, Reactions. Walter de Gruyter, Berlin.

Gathorne-Hardy FJ, Syaukani, Eggleton P. 2001. The effects of altitude and rainfall on the composition of the termites (Isoptera) of the Leuser ecosystem (Sumatra, Indonesia). J Trop Ecol 17 (17): 379393.
Grieco MAB, Cavalcante JJV, Cardoso AM, Vieira RP, Machado EA, Clementino MM, Medeiros MN, Albano RM, Garcia ES, de Souza W, Constantino R and Martins OB. 2009. Microbial community diversity in the gut of th South American Cornitermes cumulans (Isoptera: termitidae). Bull Entomol Res 99: 603-609.

Haygreen GJ, Bowyer JL. 1996. Forest Products and Wood Science, an Introduction, 3rd ed. Iowa State University Press, AMES, USA.

Haifig I, Vargo EL, Labadie P, Costa-Leonardo AM. 2016. Unrelated secondary reproductive in the neotropical termite Silvestritermes euamignathus (Isoptera: Termitidae). Sci Nat 103: 9.

Inoue T, Vijarsoen P, Abe T. 1998. Mound structure of the fungusgrowing termite Macrotermes gilvus in Thailand. J Trop Ecol 13 (1): 115-124.

Joshi PK, Singh NP, Singh N N, Gerpacio RV, Pingali PL. 2005. Maize in India: Production systems, constraints, and research priorities. DF CIMMYT, Mexico.

Juud TM, Corbin CC. 2009. Effect of cellulose concentration on the feeding preferences of the termite Reticulitermes flavipes (Isoptera: Rhinotermitidae). Sociobiology 53 (3): 775-784.

Kadarsyah A. 2005. Studi keragaman rayap pada jerami dan ampas tebu di Perusahaan Jamur PT Zeta Agro Coorporation, Brebes Jawa Tengah. Jurnal Bioscientiae (2): 17-22. [Indonesian]

Krisnha K, Weesner TM. 1970. Biology of Termites. Vol. 1. Academic Press, New York.

Lee CY.2002. Subterranean termite pests and their control in the urban environment in Malaysia. Sociobiology 40: 3-9.

Nandika D, Rismayadi Y, Diba F. 2003. Rayap: Biologi dan Pengendaliannya. Muhammadiyah University Press, Sukoharjo. [Indonesian]

Martawijaya A, Kartasujana I, Mandang YI, Prawira SA, Kadir K. 1989. Atlas kayu di Indonesia, Vol. II, Badan Litbang Kehutanan, Bogor. [Indonesian]

Oldeman LR. 1978. Climate of Indonesia. Proceeding of $6^{\text {th }}$ Asia Pacific Weed Science Society Conference, Jakarta.

Oludairo OO, Aiyedun JO, Adeyi AJ, Ayeni AMJ, Aungbias AA. 2016. Control and prevention of deterioration caused by termites (Isoptera). J Res For Wildlife Environ 8 (3): 44-50.

Pratiknyo H, Ahmad I, Budianto BH. 2018. Diversity and abundance of termites along altitudinal gradient and slopes in Mount Slamet, Central Java, Indonesia. Biodiversitas 19: 1649-1658.

Pratiknyo H, Setyowati EA. 2020. Short Communication: The diversity of termites along the altitudinal gradient in a Karst Area of Southern Gombong, Central Java, Indonesia. Biodiversitas 21: 1730-1734.

Rachmawati D. 1996. Prakiraan Kerugian Ekonomi akibat Serangan Rayap pada Bangunan Perumahan di Dua Wilayah DKI Jakarta. Fakultas Kehutanan [Hon. Thesis]. Institut Pertanian Bogor, Bogor. [Indonesian]

Rao NA, Samantha CH, Sammaiah C. 2012. Biodiversity of Termites in Badrachalam Forest Region, Khammam district, Andhra Pradesh. J Biodiversity 3 (1): 55-59.

Rust MK, Su NY. 2012. Managing social insects of urban importance. Ann Rev Entomol 57: 355-375.

Syafii W. 2006. Zat ekstraktif dan pengaruhnya terhadap keawetan alamiah kayu. Jurnal Teknologi Hasil Hutan 9 (2): 29-35. [Indonesian]

Tarumengkeng RC. 1971. Biologi dan pengenalan rayap perusak di Indonesia. Laporan Penelitian Hasil Hutan. Institut Pertanian Bogor, Bogor. [Indonesian]

Tobing TL. 2007. Pengawetan kayu. Lembaga Kerjasama Fakultas Kehutan Hutan, Institut Pertanian Bogor, Bogor. [Indonesian]

Verma M, Sharma S, Prasad R. 2009. Biological alternatives for termite control: A review. Intl J Biodeterior Biodegrad 63: 959-972.

Wahyuni N. 2000. Tingkat serangan rayap tanah pada bangunan rumah penduduk pedesaan Kabupaten Banyumas. Fakultas Biologi [Hon. Thesis] Universitas Jenderal Soedirman, Purwokerto, Banyumas. [Indonesian]

Waller DA, Jones CG, La Fage JP 1990. Measuring wood preference in termites. Entomologia Experimentalis et Applicata 56: 117-123. 